\title{
特集「外来種と植生管理」
}

\section{利根運河堤防部における在来草原性植物群落に対する 外来植物の影響評価}

\section{相澤章仁 ${ }^{* 1)} \cdot$ 田中愛子 ${ }^{2)} \cdot$ 小林弘和 $^{1)} \cdot$ 小林達明 ${ }^{1)}$}

\author{
1）千葉大学大学院 園芸学研究 Graduate School of Horticulture, Chiba University \\ 2) 千葉大学 園芸学部 Faculty of Horticulture, Chiba University
}

\begin{abstract}
摘要 : 外来種を管理・防除するためには, どの外来種が在来生態系に影響を与えているかを評価する必要があ る。本研究では千葉県北西部を流れる利根運河の堤防植生を対象として，コドラートを使ったランダムサンプリ ングによる植生調査を行い, TWINSPAN と統計モデリングを用いて外来種の在来生態系への影響評価を行っ た。TWINSPAN の結果, 対象地の植生はセイバンモロコシ・セイタカアワダチソウを指標種とした 2 つ外来 植物群落と 2 つ在来植物群落に分かれ, 統計モデリングでもこの外来種 2 種が在来種の分布に影響を与えて いることが示された。影響の度合いはセイバンモロコシの方が強く, 個体レベルでの影響 $(50 \mathrm{~cm} \times 50 \mathrm{~cm})$ と 個体群レベルでの影響 $(5 \mathrm{~m} \times 10 \mathrm{~m})$ の両方の空間レベルで在来種に影響を与えていた。セイタカアワダチソウ は個体レベルでの影響は検出されなかったため, 本種の完全排除というよりは, 低密度管理を行うことで在来種 の回復が望める可能性があることがわかった。現地において防除活動を進める際には本研究の調査方法を用いて モニタリングを進めていくことが有用であると考えられる。

キーワード：ランダムサンプリング，コドラート法，統計モデリング，モニタリング，順応的管理，利根運河
\end{abstract}

Aizawa Akihito, Tanaka Aiko, Kobayashi Hirokazu and Kobayashi Tatsuaki: Evaluation of the effect of alien plants on the indigenous grassland community on the river bank of the Tone canal

Abstract: To evaluate the effect of the alien plants on indigenous grassland ecosystem on the riverbank of the Tone canal, we did vegetation survey using random sampling method and used TWINSPAN and statistical modeling. The TWINSPAN divided the vegetation into two alien communities and two indigenous communities. The result of the statistical modeling showed that an alien indicator species Solidago altissima affected on the indigenous species only in population level scale $(5 \mathrm{~m} \times 10 \mathrm{~m})$ but not in individual level scale $(50 \mathrm{~cm} \times 50 \mathrm{~cm})$, meanwhile another alien indicator species Sorghum halepense f. muticum showed strong and multi-scale effect on the indigenous species. That means $S$. altissima affect indigenous species in large scale, but inside the population of the $S$. altissima, there can be some indigenous species inside. Thereby, regulation of the density of the S. altissima (ex: shifting the mowing season) may lead to the expansion of the indigenous species. To manage alien plants in this riverbank, we must reference to the community types divided by TWINSPAN and make an effort to bring down the density of the $S$. altissima and control expansion of the S. halepense f. muticum. Additionally, we recommend our survey method to apply monitoring not only for checking alien species reduction but also for confirming the indigenous ecosystem recovery.

Key words: random sampling, quadrat method, statistical modeling, monitoring, adaptive management, Tone canal

\section{1.はじめに}

外来種による在来生態系の破壊や産業等への影響の問題は 広く認識され始め,「特定外来生物による生態系等に係る被 害の防止に関する法律」（略称「外来生物法」）に基づいた国 レベルでの対策から, 各地方における行政・市民レベルでの 駆除活動まで様々なレベルでの防除活動が行われてい る ${ }^{12.15)}$ 。外来生物法では予防原則の考え方をもとに特定外来
生物の流通や移動・飼育を制限しているが, 既に地域に侵 入・定着してしまった外来種に対してどのような対策をと り，管理を行っていくかを具体的に示した法律やガイドライ ンは日本にはまだない ${ }^{14)}$ 。生物多様性条約第 8 条では「生態 系, 生息地若しくは種を勗かす外来種の導入を防止し又はそ のような外来種を制御し若しくは撲滅すること」が締約国の 努力義務として記載されているが, 一方で国際自然保護連合 (IUCN) が作成した外来生物による生物多様性減少防止のた

*連絡先著者（Corresponding author） =271-8510 千葉県松戸市松戸 648 E-mail : akihitoaizawa@gmail.com 
めのガイドライン では管理に当たっては外来生物を管理す ることによる明確な利得を目的として定めることが重要であ り，外来生物の減少自体を目的とするべきではないことが明 記されている。こうしたことを考虑すると，外来生物の管理 を行う際にはまず生態系や人間活動に影響を与えている外来 生物をしっかりと評価することが重要であると考えられる。

本研究で対象とする外来の草本植物に関する防除について は, 防除方法の検討や実験的に防除を行った時の在来生態系 の反応 ${ }^{4.5 .15 .17}$ に着眼が置かれ研究されることが多いが, 防除 の事前に外来種の影響を予測した研究はない。外来種の影響 予測は在来種に影響を与えやすい外来種を特定できるだけで なく, 順応的な防除計画 ${ }^{11}$ を作る際の仮説の設定や評価を明 確にすることが期待できる。

そこで本研究では千葉県北西部を流れる利根運河の堤防植 生を対象として，コドラートを使ったランダムサンプリング による植生調査を行い, TWINSPAN, 統計モデリングを用い て外来種の在来生態系への影響評価を行うことを目的とし， 現地での防除活動に有効となる知見について考察を行った。

\section{2. 方 法}

\section{1 対象地の概要}

対象地の利根運河は，利根川と江戸川を結び，千葉県野田 市，柏市，流山市の 3 市にまたがって流れる流路延長 8.5 $\mathrm{km}$ （利根川高水敷を含む）の一級河川である。利根川と江 戸川を結ぶ舟運が盛んだった時代に航路短縮を目的に人工的 に掘削され，明治 23 年に通水した（図-1）。その堤防は建 設された場所や構造に起因して，面積は狭いながらも変化に 富んだ自然環境を備えており，100 年の歴史の中で，それぞ れの環境に適した多様な植物が定着している ${ }^{24)}$ 。本研究が対 象としている堤防表法面は, 勾配は約 20 度, 法長はおよそ 6-8 m で, 切土法面の場合は天端の上も元の台地の高さまで 斜面が続いている状態である。通水当時の植生工などは不明 だが，掘削時も，その後の台風被害からの復旧工事でも客土 は行っておらず，大規模な植生工の痕跡もみられない。この ような場所でインフラ管理として年 2-3 回ほどの草刚りが 行われていることは, 非意図的ながら在来の草地性植物に

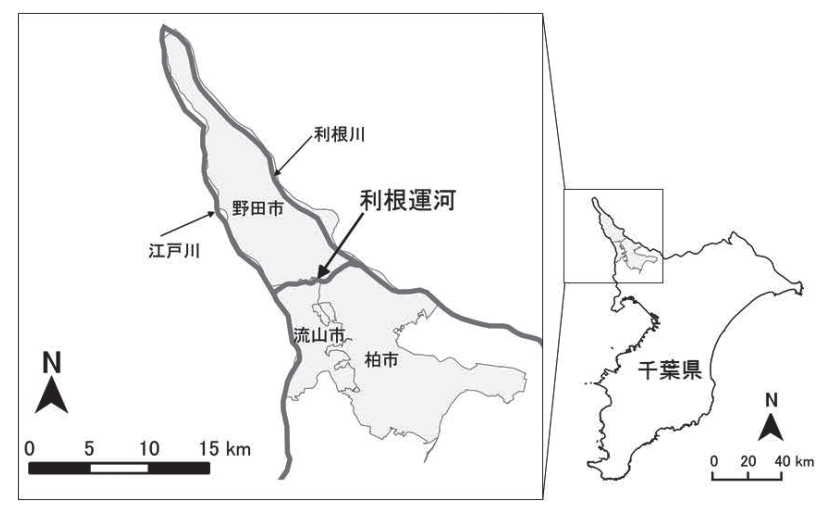

图-1 利根運河の位置

Fig. 1 Location of the Tone canal
とって良好な環境を与えており ${ }^{2,9,22)}$, 日本全国スケールで減 少が懸念されている半自然草地 ${ }^{222}$ としての価値を持った貴重 な生態系を存続させてきた。しかし, 市民団体『利根運河の 生態系を守る会』の 2003 年-2005 年の調査報告 ${ }^{24}$ において “近年工事が行われた堤防ほど外来種が多く, 植物相が貧弱 である”とコメントされるなど, 少なくとも 2003 年以前か ら, 場所によっては外来種が繁茂し, 在来植物の生育に影響 を与えている懸念がある。

河川管理者である江戸川河川事務所は, 利根運河の生態系 を守る会と意見交換をすることで順応的管理を行うことを目 指している。また外来種対策においても，インフラ管理のた めの草刈とは別に, 低水敷に繁茂している特定外来生物：ア レチウリの駆除イベントを市民参加で行うなど積極的な姿勢 が見られる。しかし, 外来種各種の在来生態系への影響評価 や, 草地性植物が生育する堤防表法面に着目した外来種対策 やモニタリングは行っておらず，仮説や客観的デー夕に基づ いた順応的管理が実施されているとは言えない。

\section{2 植生調査・モニタリング}

利根運河両岸の天端に整備されている遊歩道沿いに $50 \mathrm{~m}$ 間隔で調查地点を設置し（図-2），表法面における対象種の 出現状況を調查した。各調查地点では, 遊歩道と平行に 10 $\mathrm{m}$ ，法面に沿って $5 \mathrm{~m}$ の範囲内に $50 \mathrm{~cm} \times 50 \mathrm{~cm}$ のコドラー トを無作為に 5 つ投げて設置した。設置されたコドラート ごとに対象種を探し，被度などは考慮せず在/不在の情報を 記録した。この調査方法はコドラートの設置場所の選定や目 視による被度の測定などを行う必要がなく，専門性が低く人 為バイアスも少ない。そのためこの調查手法は客観性が必要 なモニタリング調査として有用であると言え ${ }^{13}$ ，市民参加に よるモニタリングを行う場合にも使用しやすい。調査は夏季 の草刈り（8月-9月）が終わった後の秋季の植生をターゲッ トとし， 2013 年の 10 月および 11 月に行った。ただし, KP. 2 付近から KP. 3 付近の間は公園として管理されていた ため調查対象から除いた。

本研究では空間スケールを階層的なレベルに分ける設定 ${ }^{16)}$

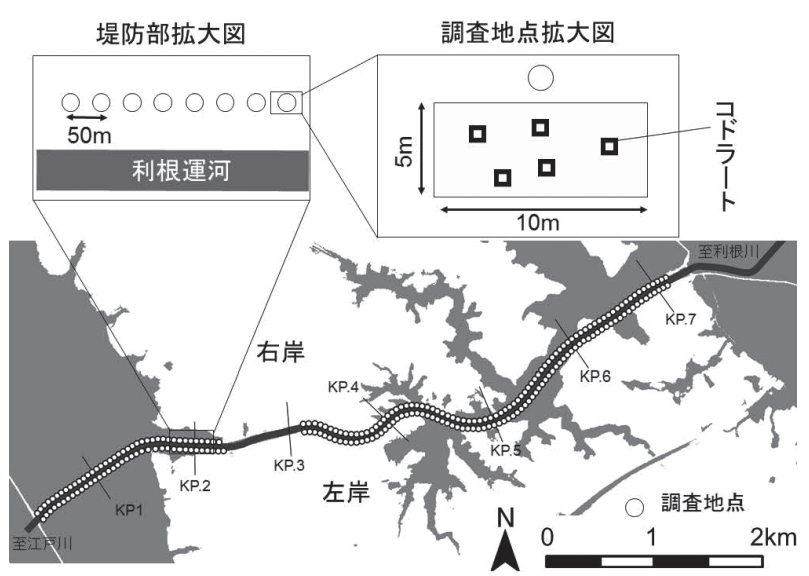

図-2 利根運河の地形と調査デザイン

Fig. 2 Topography of Tone Canal and Survey design of this study 
表-1 調查対象種

Table 1 Target species of this study

\begin{tabular}{|c|c|c|c|c|}
\hline \multirow{2}{*}{ 種 名 } & \multirow{2}{*}{ 学 名 } & \multicolumn{3}{|c|}{$\begin{array}{l}\text { 対象種を草原性植物 } \\
\text { の指標としている文献 }\end{array}$} \\
\hline & & $\begin{array}{l}\text { 金子ほか } \\
(2009)\end{array}$ & $\begin{array}{c}\text { 小柳ほか } \\
(2009)\end{array}$ & $\begin{array}{c}\text { 山田・根本 } \\
(2013)\end{array}$ \\
\hline \multicolumn{5}{|l|}{ 【草原性植物種】 } \\
\hline ノハラアザミ & $\begin{array}{l}\text { Cirsium oligophyllum (Franch. et } \\
\text { Sav.) Matsum. }\end{array}$ & - & - & $\bigcirc$ \\
\hline ツリガネニンジン & $\begin{array}{l}\text { Adenophora triphylla var. japonica } \\
\text { (Regel) H. Hara }\end{array}$ & 0 & ○ & 0 \\
\hline アキノタムラソウ & Salvia japonica Thunb. & 0 & - & $\bigcirc$ \\
\hline ナンテンハギ & Vicia unijuga A. Braun & 0 & O & 0 \\
\hline ワレモコウ & Sanguisorba officinalis $\mathrm{L}$. & - & 0 & - \\
\hline アキカラマツ & $\begin{array}{l}\text { Thalictrum minus var. hypoleucum } \\
\text { (Siebold et Zucc.) Miq. }\end{array}$ & 0 & - & 0 \\
\hline センニンソウ & Clematis terniflora DC. & O & - & - \\
\hline ツルボ & $\begin{array}{l}\text { Barnardia japonica (Thunb.) Schult. } \\
\text { et Schult. f. }\end{array}$ & 0 & - & - \\
\hline \multicolumn{5}{|l|}{ 【頻出在来種】 } \\
\hline ユウガギク & Aster iinumae Kitam. & - & - & - \\
\hline カントウョメナ & $\begin{array}{l}\text { Aster yomena var. dentatus (Kitam.) } \\
\text { H. Hara }\end{array}$ & - & - & - \\
\hline $\begin{array}{l}\text { クサフジ } \\
\text { 【外来種】 }\end{array}$ & Vicia cracca $\mathrm{L}$. & - & - & - \\
\hline ハルジオン & Erigeron philadelphicus L. & - & - & - \\
\hline セイタカアワダチソウ & Solidago altissima $\mathrm{L}$. & - & - & - \\
\hline ワルナスビ & Solanum carolinense $\mathrm{L}$. & - & - & - \\
\hline アレチウリ & Sicyos angulatus $\mathrm{L}$. & - & - & - \\
\hline セイバンモロコシ & $\begin{array}{l}\text { Sorghum halepense f. muticum } \\
\text { (Hack.) C.E. Hubb. }\end{array}$ & - & - & - \\
\hline
\end{tabular}

を取り入れており, コドラート, 調査地点という 2 つの空 間レベルが設定されている。コドラートレベル $(50 \mathrm{~cm} \times 50$ $\mathrm{cm})$ は草本植物の個体同士が日照や空間を直接奪い合うレ ベルであると考えられ，外来種と在来種の個体間の影響が現 れる空間レベルであると解釈した。調査地点レベル $(10 \mathrm{~m} \times$ $5 \mathrm{~m} ）$ は単一種が群生することにより, 他種を減少させるな ど，個体群レベルでの影響が検出される空間レベルであると 解釈した。

調査対象種は利根運河堤防に秋季によくみられる草本植物 16 種（在来種 11 種, 外来種 5 種）とした（表- 1 )。在来種 には, 主に既往研究で半自然草地の構成種として扱われてい る草原性植物種, および対象地におけるこれまでの市民調 查 ${ }^{24}$ において, 利根運河堤防部の複数の区域に出現すること が確認されている在来頻出種（カントウヨメナ, ユウガギク, クサフジ）を選定した。このうち草原性植物種については, 個別の評価に加え, それらのうち一種でもコドラート内に出 現した場合を『在』として扱ったものを『草原性植物種群』と して以降の解析で用いた。外来種については対象地で多く見 られるものや，草地で繁茂する恐れのある5 種を選定した。 2.3 解析方法

\subsubsection{TWINSPAN による群落の分類}

管理対象となる植生タイプの分布を把握するため, TWINSPAN ${ }^{7)}$ 用いて対象地の群落を分類した。群落の単位 は調査地点とし, 各対象種が調査地点内に設置した 5 つの コドラートのうちいくつに出現したかを 6 段階で示したも のを調查地点の植生データとし, 群落の分類に用いた。解析 には WinTWINS ver. 2.3 を用い, 分割は 2 段階で止め, 各 分岐に扔ける指標種も特定した。分類した群落の配置を地図
上に表し，次節に示す統計モデリングで在来種に影響を及ぼ すと判断された外来種の対策を行う場所を検討した。

\subsection{2 各外来種の在来種への影響評価}

各外来種が個体レベルあるいは個体群レベルで在来種の出 現に影響を与えているかを評価するため, 草原性植物種群と 在来種の種ごとに 2 つの空間レベルを対象とした統計モデ ル（一般化線形混合モデル，一般化線形モデル）を構築し, ベイズ推定を用いてモデルのパラメー夕を推定した。ベイズ 推定では, 観測を行ったパラメータ以外の場所差や個体差と いった統制の難しい効果を推定することができる3.10) うえ, モデルのコーディングの自由度が高く推定結果やその診断等 を精査できるという利点がある。

個体レベルでの影響評価では，1コドラート内での草原性 植物種群および各在来種の在/不在デー夕を応答変数とし, コドラートにおける 4 種の外来種（ハルジオン, セイタカ アワダチソウ，ワルナスビ，セイバンモロコシ）の在/不在 と, 環境要因（傾斜方位, 堤防の工法）を固定効果の説明変 数, 調查地点を変量効果の説明変数とする統計モデルを構築 した。環境要因は日当たりの指標として, $5 \mathrm{~m}$ メッシュ数值 標高モデル（国土交通省国土地理院の基盤地図情報ダウン ロードサービス; http://fgd.gsi.go.jp/download/）から計算 した東西方向（東向き斜面が正，西向き斜面が負）・南北方 向（北向き斜面が正，南向き斜面が負）の斜面方位 ${ }^{21}$ を標準 化したもの, および堤防の工法として, 戝-2に扔いて台地 と接している調查地点を切土法面, それ以外の地点を盛土法 面とする 2 值のカテゴリー変数（以降切土と示す）を用意 した。

コドラートレベルにおける在来種 $i$ の在/不在 $Y_{i}$ は, 式に示すようにベルヌーイ分布に従う。

\section{$Y_{i} \sim \operatorname{Bernoulli}\left(p_{i}\right)$}

在来種 $i$ が出現する，すなわち “在” である時の確率 $p_{i}$ は, (2)式で決定できる。

$$
\operatorname{logit}\left(p_{i}\right)=\cdot_{i}+\beta_{i} \times X_{i}+\varepsilon_{i k}
$$

$\bullet_{i}$ は切片のベクトル, $X_{i}$ は 7 個（東西方位, 南北方位, 切土/盛土, ハルジオン, セイタカアワダチソウ, ワルナス ビ, セイバンモロコシ) の固定効果ベクトル， $\beta_{i}$ は回帰係 数べクトル, $\varepsilon_{i k}$ は $k$ 個の調查地点から変量効果（調查地点 由来の差異）を表す。ベイズ推定では事前分布を用いて経験 等に基づく情報を予測に反映することができる ${ }^{1}$ が，今回は 未知のものとして無情報事前分布を用いた。固定効果の事前 分布は平均 0 , 精度 $10^{-4}$ の正規分布を設定し, 変量効果は 平均 0 , 精度は 0 から $10^{4}$ までの一様分布から抽出された分 散の逆数を持つ正規分布に従うよう設定した。

調査地点レベルにおける在来種 $i$ の在/不在頻度 $Y_{i}$ は, (3)式に示す二項分布に従う。

\section{$Z_{i} \sim \operatorname{Binomial}\left(q_{i}, 5\right)$}

$q_{i}$ は 5 個のコドラートに扔ける在来種 $i$ が出現する確率で ある。二項分布はベルヌーイ試行の繰り返しからなり, $q i$ の決定はベルヌーイ分布と同じ logit 変換で行うことができ る((4)式)。 


$$
\operatorname{logit}\left(q_{i}\right)=\cdot_{i}+\beta_{i} \times X_{i}
$$

$\cdot{ }_{i}, \beta_{i}, X_{i}$ はコドラートレベルの解析と同様の内容を示 す。固定効果の事前分布もコドラートレベルと同様に平均 0 ，精度 $10^{-4}$ の無情報事前分布を設定した。

以上の設定の下で繰り返しを 10 万回 50 万回に設定して 各係数の值が収束するまで（R-hat $<1.1$ を基準とした）マル コフ連鎖モンテカルロ $(\mathrm{MCMC})$ 法による各パラメータのサ ンプリングを行った。各変数の係数の $95 \%$ サンプリング区 間に 0 が入るか否かを確認し， 0 が入らない場合はその変数 が在来種の分布に影響を与えている要因であると判断した。

個別の種の解析では, 統計モデルを組めるサンプル数を考 虑して出現調査地点数が 10 筒所以上ある種のみを用いた。 斜面方位の計算には QGIS 2.2.0 リングは R ver. 3.0.2 20)を通して JAGS ver. 3.4.018)で行った。

\section{3. 結 果}

\section{1 植生調査の結果}

植生調查では対象とした種のうちアレチウリ以外のすべて の種が確認された。出現した調査地点数 $(\mathrm{n}=237)$ が多かっ たのはセイタカアワダチソウが 134 地点と全調査地点の半 分以上で確認されており, ハルジオン (74 地点), セイバン モロコシ（69 地点）と外来種が続いた。在来種ではワレモ コウ (63 地点), カントウヨメナ (52 地点), ツルボ (38 地 点）の順に出現数が多かった。コドラート数 $(\mathrm{n}=1185)$ は 多い順に，セイタカアワダチソウ（380コドラート），セイ バンモロコシ（234 コドラート)， ワレモコウ（143 コドラー ト), ハルジオン (135 コドラート), カントウヨメナ (115 コドラート), ツルボ (84コドラート), であり, ワレモコ ウとハルジオンが入れ替わった以外は同様の順位であった。

\subsection{TWINSPAN による群落の分類}

TWINSPAN によって, 調査地の堤防表法面の群落は 4 つ の植生タイプに分けられた（図-3）。第 1 分岐ではセイタカ アワダチソウ・セイバンモロコシを指標種とした外来種を中 心としたタイプと，ノハラアザミ・ツリガネニンジン・ワレ モコウ・ツルボ・カントウヨメナを指標種とした在来種を中 心としたタイプの二つに分かれた。第 2 分岐ではセイバン モロコシとセイタカアワダチソウが指標種となって分かれた ため，それぞれをセイバンモロコシ群落，セイタカアワダチ

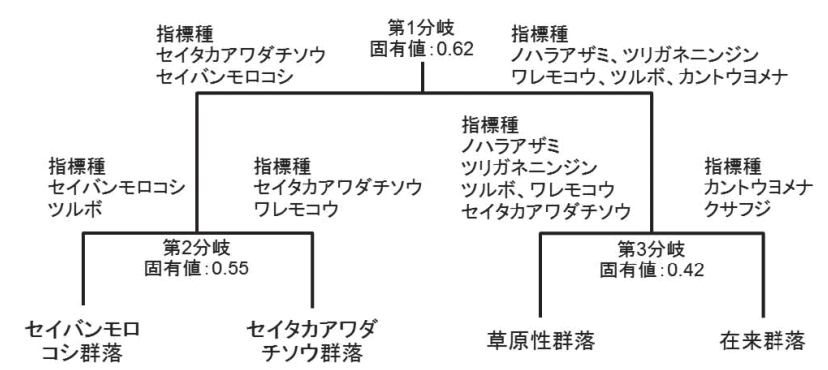

図-3 TWINSPAN による群落タイプの分類

Fig. 3 Community types of the study area calculated by TWINSPAN

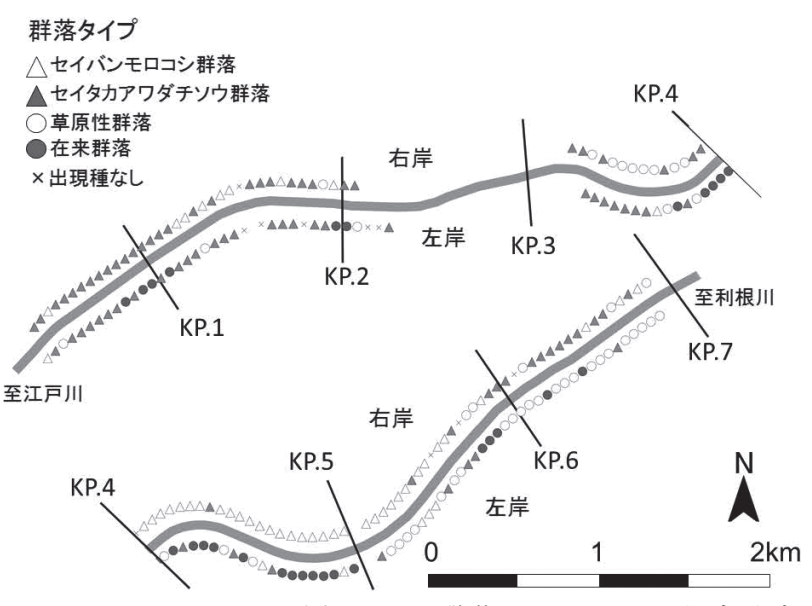

図-4 TWINSPANで分類された群落タイプによる調查地点 の区分

Fig. 4 The map of Community types calculated by TWINSPAN

ソウ群落と定義した。第 3 分岐はノハラアザミ・ツリガネ ニンジン・ワレモコウ・ツルボ・セイタカアワダチソウを指 標種とする群落と, カントウヨメナ・クサフジを指標種とす る群落の二つに分かれ, 前者を草原性群落, 後者を在来群落 と定義した。

それぞれの群落の配置を図-4に示す。右岸はほとんどが セイバンモロコシ群落とセイタカアワダチソウ群落となって いたが，KP. 3 と KP. 4 の間に保全価值が高いと考えられる 草原性群落が連続して存在していた。左岸は江戸川沿いから KP. 4 手前付近まではセイタカアワダチソウ群落が多く存在 し, KP. 4 から KP. 5 までは在来群落, KP. 5 から利根川沿 いまでは草原性群落が多くなっていた。

\section{3 各外来種の在来種への影響評価}

コドラートレベルでの各種群・種の在/不在を応答変数と した階層ベイズモデルでは, 草原性植物種群にセイバンモロ コシが負の影響を与えていた（表-2）。個別の種に対しては, セイタカアワダチソウがカントウヨメナに，セイバンモロコ シがワレモコウに負の影響を，ハルジオンがワレモコウに正 の影響を与えていた（表-2）。調査地点レベルでの各種群・ 種のコドラート数を応答変数とした結果では, 草原性植物種

表-2 コドラートレベルでの階層ベイズモデルによって推定さ れた変数の係数の中央值

Table 2 Median coefficient values of the variables estimated by hierarchical Bayesian model in individual level

\begin{tabular}{|c|c|c|c|c|c|c|c|}
\hline & $\begin{array}{l}\text { 東西 } \\
\text { 傾斜 }\end{array}$ & $\begin{array}{l}\text { 南北 } \\
\text { 傾斜 }\end{array}$ & 切土 & $\begin{array}{l}\text { ハルジ } \\
\text { オン }\end{array}$ & $\begin{array}{l}\text { セイタカア } \\
\text { ワダチソウ }\end{array}$ & $\begin{array}{c}\text { ワルナ } \\
\text { スビ }\end{array}$ & $\begin{array}{l}\text { セイバン } \\
\text { モロコシ }\end{array}$ \\
\hline 草原性植物種群 & -7.40 & - & 2.06 & - & - & - & -1.84 \\
\hline ノハラアザミ & -1.02 & - & -1.84 & - & - & - & - \\
\hline ツリガネニンジン & -6.60 & - & 2.07 & - & - & - & - \\
\hline ワレモコウ & -7.01 & - & - & 1.02 & - & - & -2.85 \\
\hline ツルボ & -1.59 & -1.34 & -1.10 & - & - & - & - \\
\hline カントウヨメナ & - & 1.43 & -0.63 & - & -0.96 & - & - \\
\hline
\end{tabular}

ナンテンハギ, ユウガギク, クサフジはパラメーターの収束が悪かったため, 解析から除いた。 一は $95 \%$ サンプリング区間に 0 が入っており有効でない変数と判断されたもの。 
表-3＼cjkstart調査地点レベルでの階層ベイズモデルによって推定され た変数の係数の中央值

Table 3 Median coefficient values of the variables estimated by hierarchical Bayesian model in population level

\begin{tabular}{|c|c|c|c|c|c|c|c|}
\hline & $\begin{array}{l}\text { 東西 } \\
\text { 傾斜 }\end{array}$ & $\begin{array}{l}\text { 南北 } \\
\text { 傾斜 }\end{array}$ & 切土 & $\begin{array}{l}\text { ハルジ } \\
\text { オン }\end{array}$ & $\begin{array}{l}\text { セイタカア } \\
\text { ワダチソウ }\end{array}$ & $\begin{array}{c}\text { ワルナ } \\
\text { スビ }\end{array}$ & $\begin{array}{l}\text { セイバン } \\
\text { モロコシ }\end{array}$ \\
\hline 草原性植物種群 & -0.52 & -0.46 & 0.49 & 0.22 & -0.32 & - & -0.54 \\
\hline ツリガネニンジン & -0.73 & - & 0.63 & - & -0.65 & - & -0.74 \\
\hline ナンテンハギ & - & -0.75 & 0.51 & - & - & 0.27 & - \\
\hline ワレモコウ & -0.61 & - & 0.29 & - & -0.31 & - & -0.92 \\
\hline ツルボ & -0.72 & -0.62 & 0.60 & - & - & - & - \\
\hline カントウヨメナ & - & 0.60 & 0.28 & - & -1.09 & - & - \\
\hline
\end{tabular}

ノハラアザミ, ユウガギク,クサフジはパラメーターの収束が悪かったため, 解析から除いた。 一は 95\% サンプリング区間に 0 が入っており有効でない変数と判断されたもの。

群にはセイタカアワダチソウとセイバンモロコシが負の影響 を，ハルジオンが正の影響を与えていた（表-3）。個別の種 に対してはセイタカアワダチソウがツリガネニンジン, ワレ モコウ, カントウヨメナに, セイバンモロコシがツリガネニ ンジン, ワレモコウに負の影響を, ワルナスビがナンテンハ ギに正の影響を与えていた（表-3）。

コドラートレベルにおけるナンテンハギ, ユウガギク, ク サフジ, 調査地点レベルにおけるノハラアザミ, ユウガギ ク, クサフジは繰り返しを 50 万回に設定してもパラメー ターが収束しなかったため, 解析対象から除いた。

\section{4. 考察}

今回の調査結果から, 利根運河の堤防植生ではセイタカア ワダチソウ・セイバンモロコシをはじめとする外来種が多く 繁茂していることが定量的に示された。TWINSPAN の結果 では, 群落夕イプが第 1 分岐でセイバンモロコシ・セイタ カアワダチソウと数種の在来種を指標として分岐した上, 半 数以上の調査地点がそれらの群落に属していた（図-4）。こ のことは, これらの外来種 2 種が利根運河河川敷の広い範 囲で群落を作っていることを示している。統計モデリングに よる各外来種の影響評価でも, この 2 種は草原性植物種群 をはじめ多くの在来種に影響を与えていた。セイタカアワダ チソウとセイバンモロコシの推定された係数の中央值を比べ てみると, 全体的にセイバンモロコシの方がより係数が大き く, セイタカアワダチソウよりも大きな影響を在来種に与え ていることがわかった。

また,これら 2 種が影響する空間スケールに着目しなが ら統計モデリングの結果（表-2，3）を見ると, セイタカア ワダチソウから個体群レベルでのみ影響を受け, 個体レベル では影響を受けない在来種が多くみられた。これはセイ夕カ アワダチソウが個体群として広がる中に在来種が混在して存 在している状況にあると考えられる。セイタカアワダチソウ は一度定着すると地下茥によって急速に広がり, 高茎によっ て在来種を駆逐することが知られているが6 ${ }^{6}$ 本研究の対象地 ではそうした状況にないことがわかった。これは利根運河に おいて, 河川管理の一環として頻繁に草刚りが行われてきた ことがセイタカアワダチソウの密度抑制につながった可能性

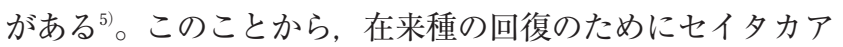

ワダチソウを管理する場合には，セイタカアワダチソウを低 密度に抑えて在来種が生育できる場所を局所的に確保するこ とが肝要であり, 必ずしもセイタカアワダチソウの根絶を目 指す必要はないと考えられる。セイタカアワダチソウは頻繁 な草刚りによって被度や草丈が抑制されることや ${ }^{5)}$, 地下部 へのバイオマス分配が顕著に大きくなる 8 月以前に地上部 を刈り取ることによって繁茂が抑制されること ${ }^{23}$ なども報告 されており，バイオマス配分などの季節変化に合わせた草刚 の時期の検討も有効であろう。

一方で, セイバンモロコシではコドラートレベル・調査地 点レベルの両方で影響を及ぼしており, 個体・個体群の両レ ベルで在来種を排除している状況にあると考えられる。セイ バンモロコシの防除に関する既往研究は少ないため, 効果的 な防除方法は不明であるが，現在残されている在来生態系へ の侵入拡大を防ぐことが最も重要であると考えられる。

ワルナスビとハルジオンは在来種に対して負の影響を与え ることは確認されなかった。ワルナスビは出現地点数が少な いため, その効果を十分検出することができなかったと考え られる。ワルナスビは出現範囲が狭いため当面は対策を練る 必要がないと思われるが, 今回出現が見られなかったアレチ ウリと共に, 堤防法面において分布が広がっていくかどうか をモニタリングしていく必要がある。ハルジオンについては 出現地点数が多いにもかかわらず, 在来種に対して負の影響 を与えることはなかった。今回調査を行った 10 月から 11 月ではハルジオンは開花期が終わりロゼット期へと移行して いる状態であるが，ロゼット期と開花期で分布は変化しない ものと考えられるので，ハルジオンが開花期に対象とした秋 季植物の芽生えに影響を与えて個体数を減らすといった作用 もないものと考えられる。利根運河堤防部の秋季の在来植物 保全のためには, ハルジオンは外来種防除の対象とする必要 性は低い種類であると言える。ただし, 現在は在来種に影響 を与えていない種でも, 大きな影響を与えている種を防除し たときなどに意図しない効果 ${ }^{25,28)}$ を生態系に影響を与え始め る恐れがあるため, モニタリングは続けて行く必要がある。 また, ワルナスビとハルジオンについては一部の種・種群に 正の影響を与えていることがわかったが，生態系エンジニア としてこれらの種が機能するという報告はないため, 対象 種・種群の生育を促進したと考えるより, これらと同所的に 存在することができる種であると考える方が妥当である。

今回用いた環境要因では，東西傾斜が多くの種に負の影響 を与え, 南北傾斜がいくつかの種に負の影響を与えていた。 これは西側斜面, 南側斜面に今回対象とした種が多く存在す ることを示している。南側斜面は日当たりの良さを表してい ると考えられるが, これは草原性植物が明環境を好むという 先行研究と一致する結果である ${ }^{26)}$ 。西側斜面の影響について はなんらかの要因が関係している可能性があるが, 詳細のメ カニズムについては今後調べていく必要がある。また, 切土 も多くの種に正の影響を与えていた。利根運河は谷津地形を 利用して作られた運河であり, 切土斜面では所々に湧水がし み出している場所が見られ，湿潤な環境となっている ${ }^{24)} 。 セ$ 
イタカアワダチソウは乾燥に対する抵抗力が強いとされてお $\eta^{6}$ ，牧草由来であるセイバンモロコシもこれに準ずる性質 を持っていると考えられるが，湿潤な切土法面ではこれらの 外来種の在来種への影響が緩和されたり，外来種が初期侵入 しにくい状態となっていたなどの可能性が考えられる。この メカニズムについても推察の域を超えないので，別途検証を 行う必要がある。

\section{5. まとめ}

本研究ではコドラートを使ったランダムサンプリングを行 い，TWINSPAN および統計モデリングを使用することによ り, 利根運河の堤防植生を事例とした外来草本植物の在来植 物への影響評価を行うことができた。

今後この評価をもとに利根運河の堤防において秋季の在来 生態系の回復を目標とした防除活動を行っていく場合はセイ バンモロコシ・セイタカアワダチソウをターゲットとし， セ イバンモロコシは新たな場所への侵入や分布拡大を防ぐ管理 を, セイタカアワダチソウは草刚り時期の調節などを行って 低密度に抑える管理を実施することが有効であろう。

防除活動を重点的に行っていく場所を設定する場合は, TWINSPAN によって分類された群落の配置（図-4）を参照 しながら，西側・南側斜面で切土である場所を優先的に管理 していくことで，より多くの在来種を保全することが可能に なるだろう。例えばTWINSPAN の結果右岸で唯一草原性群 落が固まって存在している KP. 3 から KP. 4 の間は西側斜面 で切土であり, セイバンモロコシ群落・セイタカアワダチソ ウ群落と隣接している。これらの草原性群落に, 隣接する外 来種群落から外来種が侵入して, 草原性在来種を劦かす可能 性があるので，この部分を防除強化区間として集中的な管理 を実施することが必要であろう。なお，本研究では調査対象 種が限定されていること，秋季のみにしか調査を行っていな いため, 調查対象外となった希少種の保全や他の季節の植生 への影響なども別途並行して対策などを考える必要がある。

外来種防除を行う際にはモニタリングを行いながらどのよ うな管理が良い結果をもたらすかを検討していく順応的管理 を行うことが望まれる ${ }^{11}$ 。今回用いたコドラートを投げてラ ンダムサンプリングを行う方法は, 市民参加型のモニタリン グ方法としても有効なものである ${ }^{13,27)}$ 。こうした簡易でかつ 高度な解析に耐えうるモニタリング方法の開発・提案も, 外 来種の管理においては重要な課題であると考えられる。

謝辞 : 本研究を進めるにあたり利根運河の生態系を守る会の みなさまには調查方法の検討, 対象植物の選定・同定などに おいてご意見・ご指導をいただいた。国土交通省江戸川河川 事務所調査課のみなさまには, 利根運河堤防部の管理方法な どについて詳細をご教示いただいた。また，千葉大学大学院 園芸学研究科の梅木清准教授, 水崎大二郎氏には階層ベイズ モデルに関する様々な知見をいただいた。北海道大学理学部 の仲岡雅裕教授には，ランダムサンプリングに関する適切な アドバイスをいただいた。最後に, 編集委員と匿名の 2 名
の査読者には有益なコメントをいただいた。以上の方々に心 から御礼申し上げます。

\section{引用文献}

1）浅田正彦・長田穣・深澤圭太・落合啓二（2014）状態空間 モデルを用いた階層べイズ推定法によるキョン (Muntiacus reevesi) の個体数推定, 哺乳類科学, 54 (1): 53-72.

2）浅見佳世・服部保・赤松弘治（1995）河川堤防植生の刈り 取り管理に関する研究, ランドスケープ研究, 58(5)：125128.

3）深澤圭太・角谷拓（2009）始めよう! ベイズ推定による デー夕解析, 日本生態學會誌, 59(2): 167-170.

4）畠瀬頼子 - 小栗ひとみ・藤原宣夫 - 宇津木栄津子 - 戸井可 名子・井本郁子・松江正彦 (2009) 木曾川に扔けるオ才キ ンケイギク優占群落での啋河原植生復元のための植生管理 の効果, ランドスケープ研究, 72(5): 537-542.

5）服部保・赤松弘治 - 浅見佳世 - 武田義明（1993）河川草地 群落の生態学的研究, セイタカアワダチソウ群落の発達押 よび種類組成に及ぼす刈り取りの影響, 人と自然 (2)：105118.

6）服部保（2002）セイタカアワダチソウ, 日本生態学会偏, 外来種ハンドブック, 地人書館, 東京, pp. 196.

7) Hill, M.O. (1979) TWINSPAN - A FORTRAN program for arranging multivariate data in an ordered two-way table by classification of the individuals and attributes. Cornell University, Ithaca.

8) IUCN (2000) IUCN guidelines for the prevention of biodiversity loss caused by alien invasive species.

9）小柳知代 - 楠本良延 - 山本勝利 - 武内和彦 (2009) 年二回 の草刈りによって成立する道路沿い林縁部刈取草地におけ る草原生植物の生育状況, ランドスケープ研究, $72(5)$ : 507-510.

10）久保拓弥 (2012) デー夕解析のための統計モデリング入門, 岩波書店.

11）松田裕之 - 矢原徹一 - 竹門康弘 - 波田善夫 - 長谷川眞理 子・日鷹一雅・ホーテスシュテファン・角野康郎・鎌田麿 人 - 神田房行 - 加藤真 - 國井秀伸 - 向井宏 $\cdot$ 村上興正 $\cdot$ 中 越信和 - 中村太士 - 中根周歩 - 西廣美穂 - 西廣淳 - 佐藤利 幸・嶋田正和 - 塩坂比奈子 - 高村典子 - 田村典子 - 立川賢 一・椿宜高・津田智・鷲谷いづみ（2005）自然再生事業指 針, 保全生態学研究, 10: 63-75.

12）村中孝司 - 石井潤 - 宮脇成生・熟谷いづみ（2005）特定外 来生物に指定すべき外来植物種とその優先度に関する保全 生態学的視点からの検討, 保全生態学研究, 10(1): 19-33.

13）仲岡雅裕・渡辺健太郎（2011）アマモ場の生物多様性・生 態系モニタリング，海洋と生物，33(4): 315-322

14）日本生態学会 (2002) 外来種ハンドブック, 地人書館, 東 京, pp. 39-46.

15）西廣淳・西口有紀 - 西廣美穂 - 鷲谷いづみ（2007）湿地再 生における外来植物対策 : 霞ヶ浦の湖岸植生帯再生地にお ける市民参加型管理の試み, 地球環境, 12(1): 65-80.

16) Noda, T. (2004) Spatial hierarchical approach in community ecology: a way beyond high context-dependency and low predictability in local phenomena. Population Ecology, 46 (2), 105-117.

17）大澤剛士・赤坂宗光（2009）特定外来生物オオハンゴンソ ウの管理方法: 引き抜きの有効性の検討, 保全生態学研 究, 14 (1): 37-43. 
18) Plummer (2003) JAGS: A program for analysis of Bayesian graphical models using Gibbs sampling.

19) QGIS Development Team (2014) QGIS Geographic Information System. Open Source Geospatial Foundation Project, http://qgis.osgeo.org/

20) R Core Team (2013) R: A language and environment for statistical computing. R Foundation for Statistical Computing, Vienna, Austria, URL http://www.R-project.org

21) Stage, A.R. (1976) Notes: An expression for the effect of aspect, slope, and habitat type on tree growth. Forest Science, 22(4): 457-460.

22) 高橋佳孝 (2004) 半自然草地の植生持続をはかる修復・管 理法, 日本草地学会誌, 50(1): 99-106.

23）富沢美和・熟谷いづみ（1998）フジバカマとセイタカアワ ダチソウの夏季における地上部喪失に対する反応 : 復元植 生の管理計画を立てるために, 保全生態学研究, 3(1): 57-67.
24）利根運河の生態系を守る会（2006）利根運河の花ごよみ, 利根運河の生態系を守る会.

25）亘悠哉 (2011) 外来種を減らせても生態系が回復しないと き：意図せぬ結果に潜むプロセスと対処法を整理する，哺 乳類科学, 51(1): 27-38.

26）山田晋 - 大久保悟 - 北川淑子 - 武内和彦（2005）丘陵地谷 底水田に接する下部谷壁斜面下端の刚り取り草原における 植物種組成と環境要因との対応，ランドスケープ研究， 68 (5): 675-678.

27）吉田正人 · 河内直子・仲岡雅裕（2007）市民参加型モニ夕 リングとリモートセンシングとの統合的利用による海草藻 場の空間動態の解析, 保全生態学研究, 12(1): 10-19.

28) Zavaleta, E.S., Hobbs, R.J., \& Mooney, H.A. (2001) Viewing invasive species removal in a whole-ecosystem context. Trends in Ecology \& Evolution, 16(8): 454-459.

(2015. 5. 1 受理) 